\title{
ARTIFICIAL NEURAL NETWORKS (ANN) FOR HEIGHT ESTIMATION IN A MIXED-SPECIES PLANTATION OF Eucalyptus globulus LABILLAND Acacia mearnsii DE WILD
}

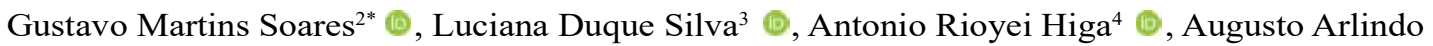 \\ Simon $^{5}$ a and Jackson Freitas Brilhante de São José ${ }^{6}+$
}

\footnotetext{
${ }^{1}$ Received on 12.08.2020 accepted for publication on 29.01.2021.

${ }^{2}$ Universidade de São Paulo, Doutor em Recursos Florestais, Piracicaba, SP - Brasil. E-mail: <gustavo.m.soares@alumni.usp.br>.

${ }^{3}$ Universidade de São Paulo, Departamento de Ciências Florestais, Piracicaba, SP - Brasil. E-mail: <lucianaduques@usp.br>.

${ }^{4}$ Universidade Federal do Paraná, Departamento de Ciências Florestais, Curitiba, PR - Brasil. E-mail: <antonio.higa@gmail.com>.

${ }^{5}$ Tanagro S.A Montenegro, RS - Brasil. E-mail: <aasimon@tanac.com.br>.

${ }^{6}$ Secretaria da Agricultura, Pecuária e Desenvolvimento Rural, Porto Alegre, RS - Brasil. E-mail: <jackson-jose@agricultura.rs.gov.br>.

*Corresponding author.
}

\begin{abstract}
The objective of this study is to evaluate the fit of Artificial Neural Networks (ANN) for height estimation and evaluation of the effects of consortium in a mixed-species plantation of Eucalyptus globulus (E) and Acacia mearnsii (A). The experiment was installed in 2005, on two farms in the municipality of Piratini - RS, where was planted the species Eucalyptus globulus (E) and Acacia mearnsii (A), in monoculture and mixed in simple lines (50\%E:50\%A - SL), and double lines (50\%E:50\%A - DL). The training and evaluation of the networks were made in R-project with the package neuralnet. All ANNs, from the simplest to the most complex, showed high values for Rŷy and low for Syx, BIAS and RMSE, with superior results in ANN 3, 4, and 6, which demonstrates that the information of DBHmin, DBHmean, and DBHmax were important stand attributes. Furthermore, the ANNs were able to capture the different growth patterns shown by the species in the different forms of consortiums, therefore is indicated for the height estimation in monocultures and mixed plantations of Eucalyptus globulus and Acacia mearnsii, and only one ANN would be necessary to represent the entire population.
\end{abstract}

Keywords: Artificial Intelligence; Hypsometric Relationship; Consortium.

\section{REDES NEURAIS ARTIFICIAS (RNA) PARA ESTIMATIVA DE ALTURA EM UM PLANTIO MISTO DE Eucalyptus globulus LABILL E Acacia mearnsii DE WILD}

\begin{abstract}
RESUMO - O objetivo desse estudo é avaliar o ajuste das Redes Neurais Artificiais (RNA) para estimativa de altura e avaliação dos efeitos do consórcio em um plantio misto de Eucalyptus globulus (E) e Acacia mearnsii (A). O experimento foi instalado em 2005, em duas fazendas no município de Piratini - RS, onde foram plantadas as espécies Eucalyptus globulus (E) e Acacia mearnsii (A), em monocultura e plantio misto em linha simples (50\%E:50\%A - LS) e linhas duplas $(50 \%$ E:50\%A - LD). O treinamento e a avaliação das redes neurais foram realizados no software R-project com o pacote neuralnet. Todas as RNAs, desde as mais simples até as mais complexas apresentaram altos valores para Rŷy e baixos para Syx, VIÉS e RQEM, com resultados superiores nas RNA 3, 4 e 6, o que demostrou que as informações DAPmin, DAPmed e DAPmax são importantes atributos do povoamento. Além disso, as RNAs foram capazes de captar os diferentes padrões de crescimento demonstrados pelas espécies as diferentes formas de consórcio, sendo indicadas para a estimativa de altura em monoculturas e plantios mistos de Eucalyptus globulus e Acacia mearnsii, e apenas uma RNA pode ser necessária para representar toda a população.
\end{abstract}

Palavras-Chave: Inteligência Artificial; Relação Hipsométrica; Consórcio.

Silf $(c)$ EY

Revista Árvore 2021;45:e4512

http://dx.doi.org/10.1590/1806-908820210000012 


\section{INTRODUCTION}

Forest management requires the managers to make decisions regarding technical, environmental, social, political and mainly economic elements, with the main objective of obtaining wood products, as well as environmental services in a sustainable way. In order to efficiently explore the timber forest resource, it is necessary to know the growing and harvesting stock by measuring and estimating the characteristics of the trees and the area in which they are planted. This originated several studies with the purpose of developing techniques and tools to assist forest managers in decision making. (Binoti, 2012).

According to Souza (2006) and Colbert et al. (2002), the measurement of tree heights is an onerous task and subject to great errors (Zanon et al., 1996; Leite and Andrade, 2003), and the measurement of diameter at the breast height (DBH) is much easier to perform, so many researchers have studied the relationship between diameter and height, called hypsometric relationship, with the interest of reducing the cost and time of data collection of height in the field (Jorge et al., 2009), measuring only the total height of some trees (Ker and Smith, 1957) and estimating the remaining trees by hypsometric equations (Andrade et al., 2011).

The simplest hypsometric models use only the independent variable $\mathrm{DBH}$, but this type of model does not always result in precise estimates, since tree height is also dependent on site, age, density, crown size, species, and other factors (Loetsch et al., 1973; Finger, 1992; Scolforo, 1997; Campos and Leite, 2009). Thus, the inclusion of stand variables such as dominant height $(\mathrm{DH})$, age and sectional area (SA) may result in more accurate height estimates (Campos and Leite, 2009), allowing to differentiate the total height of trees of the same $\mathrm{DBH}$, in places with different productive capacity (Leite and Andrade, 2003).

Dykstra (1984) lists some of the problems that can sometimes occur when using mathematical resources to model a real problem: possibility of omission of important relationships; size and complexity; excessive simplification of the relationships considered (underfitting); and at the other extreme, excessive detailing of these relations (overfitting).
Several linear and nonlinear regression models have been used for growth and yield prediction, as well as for the hypsometric relationship, however, due to the bias detected in the least squares assumptions and relatively high values in the estimation errors, Artificial Neural Networks (ANN) are being used as an alternative procedure for regression analysis (Diamantopoulo, 2005).

The ANN are parallel distributed processors composed of simple processing units (artificial neurons) linked between each other in a specific way to perform a certain task (Bullinaria, 2014), which store experimental knowledge (learning), making it available for use (generalization) (Braga et al., 2000; Haykin, 2001; Binoti, 2010).

ANN studies are justified by several useful properties and capabilities such as: error and data dispersion tolerance, learning and generalization from training data, massive parallelism that makes them very efficient, uniformity of analysis and design, analogy neurobiological, input-output mapping, nonlinearity, the ability to model several variables and the ability to model with categorical (qualitative) variables, in addition to numerical (quantitative) (Braga et al., 2000; Haykin, 2001; Bullinaria, 2014). For these reasons, in some cases, ANNs have performed better than the regression models (Binoti, 2012) and are becoming a very popular estimation tool, provided they do not need assumptions about the shape of the fit model (Dowla and Rogers, 1995; Gurney, 1999).

The objective of this study is to evaluate the fit of Artificial Neural Networks (ANN) for height estimation and evaluation of the effects of consortium in mixed-species plantation of Eucalyptus globulus and Acacia mearnsii.

\section{MATERIALS AND METHODS}

\subsection{Area Characteristic}

The experiment was installed in 2005, in two farms (Santa Maria and Camboatá), located in the municipality of Piratini - RS. The climate of the region, according to Köppen is classified as subtropical, type $\mathrm{Cfa}$, with average temperature of the coldest month between $-3^{\circ}$ and $18^{\circ} \mathrm{C}$ and temperature of the hottest month above $22^{\circ} \mathrm{C}$, the annual rainfall is around 1400 $\mathrm{mm}$, the air relative humidity about $75-85 \%$ (Moreno, 1961).

Revista Árvore 2021;45:e4512 


\subsection{Experimental Design}

In the experiment, the Eucalyptus globulus (E) and Acacia mearnsii (A) species were planted with seeds from a seed production area and inoculated with Bradyrhizobium spp.; in addition each seedling, independently of the species, received $50 \mathrm{~g}$ of organomineral fertilizer (N-P-K 04-12-08); in four treatments using square plots $(30 \mathrm{~m} \times 30 \mathrm{~m})$, with different arrangements, these being: Eucalyptus globulus in the arrangement $3 \mathrm{~m} \mathrm{x} 2 \mathrm{~m}$, containing 56 trees in the plot (833 trees / ha) + Acacia mearnsii in the arrangement $3 \mathrm{mx} 1.5 \mathrm{~m}$, with 68 trees in the plot (1,111 trees / ha), planted in simple line (50\% E: $50 \%$ A - SL), Eucalyptus globulus in the arrangement $3 \mathrm{~m} \mathrm{x}$ $2 \mathrm{~m}$, with 56 trees in the plot (833 trees / ha) + Acacia mearnsii in the arrangement $3 \mathrm{~m} \mathrm{x} 1.5 \mathrm{~m}$, covering 68 trees in the plot $(1,111$ trees / ha), planted in double line (50\% E: $50 \%$ A - DL), the monoculture of Acacia mearnsii in the arrangement $3 \mathrm{~m} \mathrm{x} 1,5 \mathrm{~m}$, with 136 trees in the plot $(2,222$ trees / ha) $(100 \% \mathrm{~A})$ and the monoculture of Eucalyptus globulus in the $3 \mathrm{~m} \times 2 \mathrm{~m}$ arrangement, with 112 trees in the plot (1,667 trees / ha) $(100 \%$ E) ), presented in Figure 1, arrangements used in the commercial plantations of each species in the region. The plots were distributed in a randomized complete block design, with double external border, with 2 blocks in each one of the farms, totalizing four blocks. It is important to emphasize that the parcels were installed in the border of the two farms, so they are geographically close.

\subsection{Growth assessments}

To evaluate the effects of the mixed-species and their arrangement in the development of the species, the circumference at the breast height $(\mathrm{CBH})$ was determined, using tape measure with precision of 1 $\mathrm{mm}$, and the total height $(\mathrm{H})$, with the aid of the Vertex hypsometer with an accuracy of $0.1 \mathrm{~m}$, of all the trees of each species in each plots, excluding only the borders, in October of the years of 2006, 2007, 2008, 2009, 2010, 2011, 2012 and 2013; which correspond to $12,24,36,48,60,72,84$ and 96 months of age.

\subsection{Training of Artificial Neural Networks (ANN)}

The trained ANN were multilayered perceptrons, popularly known as MLP (Multilayer Perceptron), which consist of two layers of artificial neurons that process the data (intermediate and output layers)

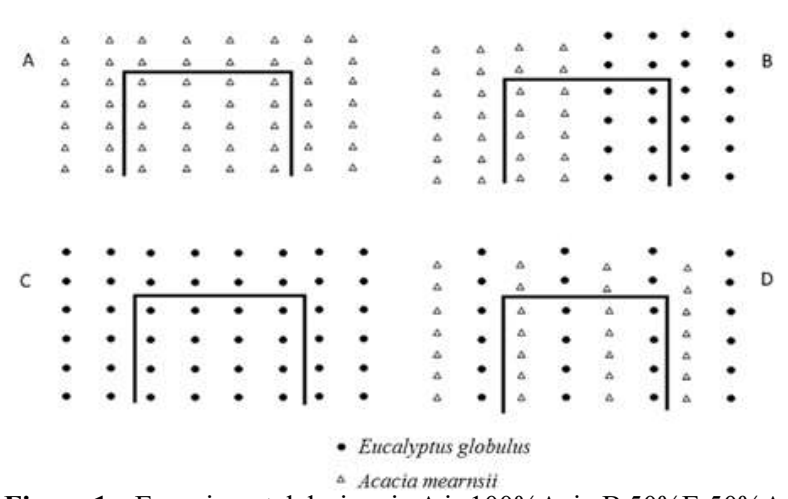

Figure 1 - Experimental design, in A is 100\%A, in B 50\% $-\mathrm{DL}$, in $\mathrm{C} 100 \% \mathrm{E}$ and $\mathrm{D}$ is the $50 \% \mathrm{E}: 50 \% \mathrm{~A}-\mathrm{SL}$, and in highlight in each treatment is observed the measurement plot.

Figura 1 - Delineamento experimental, sendo A como $100 \%$, $B$ como 50\%E:50\% - DL, C como $100 \% E$ e D como50\%E:50\%A-SL, e destacado em cada tratamento observamos a parcela de medição.

and a layer that only receives the data (input layer) and directs them to the middle layer. The training and validation of the networks were performed in R-Project with the package Neuralnet (Günther and Fritsch, 2010).

In order to obtain the ANNs to model the height of the entire data set, the treatments and species were used as categorical variables and as continuous variables Age, DBH, Height $(\mathrm{H})$, dominant height (DH), Mean DBH (DBHmean), maximum DBH (DBHmax), minimum DBH (DBHmin) and Sectional Area (SA). In addition to the several different variables, two different architectures were tested presented in Figure 2.

The training dataset contained of $70 \%$ of all data and the validation $30 \%$. For all ANN the same training and validation dataset was used. As functions of activation of the input, hidden and output layers was used the sigmoidal function. The learning algorithm used was the resilient propagation (Riedmiler and Braun, 1992), considering the basic variation denominated RPROP + (Riedmiler and braun, 1993).

\subsection{Evaluation and selection of models}

The best ANNs were selected based on the Pearson Correlation Coefficient between the observed height and the estimated height (Rŷy), the standard error of the residue (Syx), the bias of the estimates (BIAS), the root mean square error (RMSE) and the 


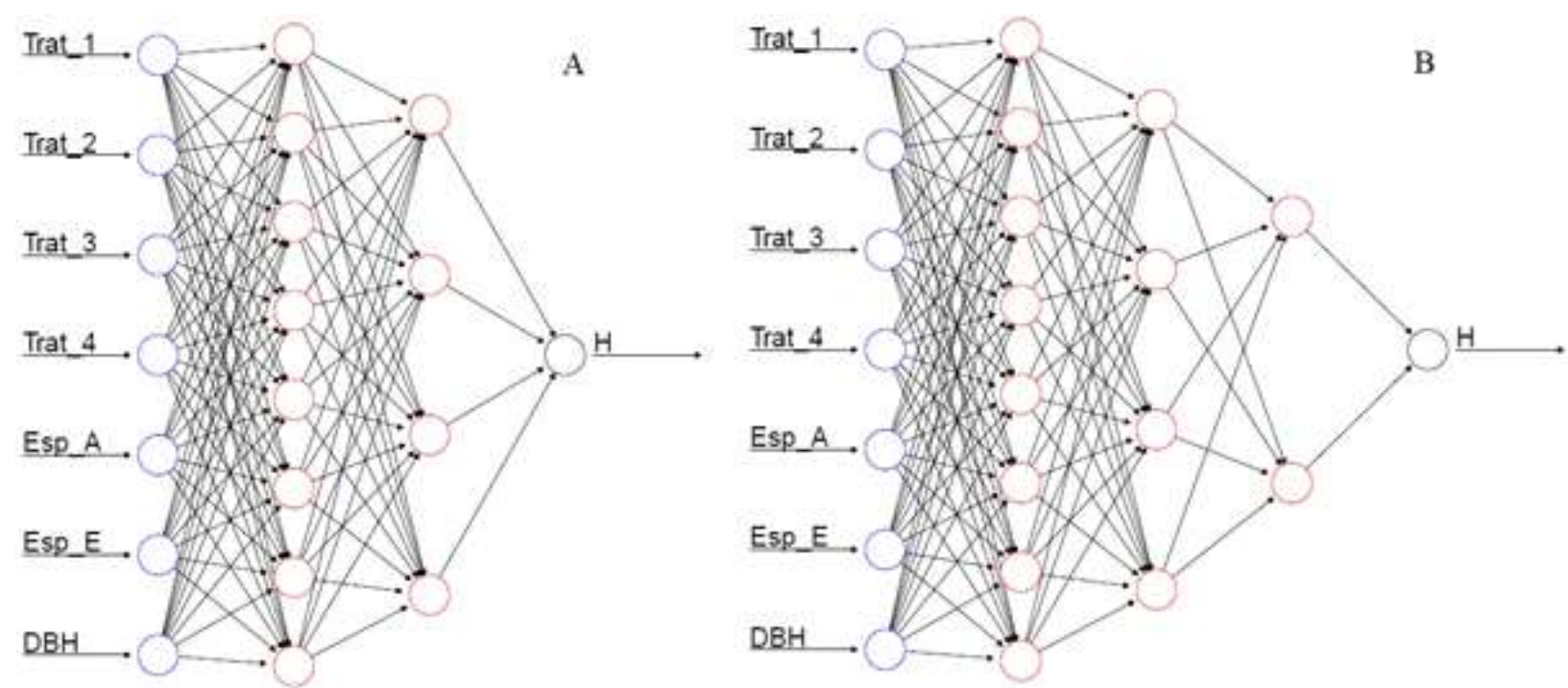

Figure 2 - Architecture of the tested ANN's, being A: 8-4-1 and B: 8-4-2-1.

Figura 2 - Arquitetura das RNA's testadas, sendo A: 8-4-1 e B: 8-4-2-1.

dispersion of the percentage errors for the training and validation dataset.

$$
\begin{array}{ll}
\mathrm{R}_{\widehat{\mathrm{yy}}}=\operatorname{Côv}(\widehat{\mathrm{Y}}, \mathrm{Y}) / \sqrt{\operatorname{Var}(\widehat{\mathrm{Y}}) \operatorname{Var}(\mathrm{Y})} & \mathrm{S}_{\mathrm{xy}}=\sqrt{\mathrm{MSE}} \\
\text { BIAS }=\mathrm{n}^{-1} \sum_{\mathrm{i}=1}^{\mathrm{n}}\left(\mathrm{Y}_{\mathrm{i}}-\widehat{\mathrm{Y}}_{\mathrm{i}}\right) & \mathrm{RMSE}=100 \overline{\mathrm{Y}}^{-1} \sqrt{\mathrm{n}^{-1} \sum_{\mathrm{i}=1}^{\mathrm{n}}\left(\mathrm{Y}_{\mathrm{i}}-\widehat{\mathrm{Y}}_{\mathrm{i}}\right)}
\end{array}
$$

where: $\hat{\mathrm{Y}}_{\mathrm{i}}, \mathrm{Y}_{\mathrm{i}}$ and $(\overline{\mathrm{Y}})$ are, respectively, observed value, estimated value by ANN and average of observed values, $\mathrm{n}$ is the number of observations,
MSE the mean square of the error, Côv covariance and Var the variance.

\section{RESULTS}

As shown in Table 1 all ANNs, from the simplest to the most complex, presented higher values for Ryy, ranging from 0.962 to 0.983 and lower for Syx, from 0.97 to 1.5 , BIAS with values between $-0,004$ and 0,005 and the RMSE, between 7.24 to 11.18 .

These observations are corroborated with the

Table 1 - Characteristics of artificial neural networks (ANN) used to estimate the height of the trees, as well as the values of the statistics used for the selection of the models that best fit the data.

Tabela 1 - Características das redes neurais artificiais (RNA) utilizadas para estimar a altura das árvores, bem como os valores das

\begin{tabular}{|c|c|c|c|c|c|c|c|}
\hline$\overline{\mathrm{ANN}}$ & Categorical Input & Continuous Input & Architecture & $\overline{\mathrm{R}_{\hat{y} y}}$ & $\mathrm{~S}_{\mathrm{yx}}$ & BIAS & $\overline{\mathrm{RMSE}}$ \\
\hline$\overline{1}$ & Treatment, Species & $\overline{\mathrm{DBH}}$ & $8-4-1$ & 0.962 & 1.50 & -0.003 & 11.18 \\
\hline 2 & Treatment, Species & $\overline{\mathrm{DBH}}$ & $8-4-2-1$ & 0.962 & 1.50 & -0.004 & 11.18 \\
\hline 3 & Treatment, Species & DBH, DBHmean, DBHmax, DBHmin & $8-4-1$ & 0.984 & 0.98 & 0.003 & 7.30 \\
\hline 4 & Treatment, Species & DBH, DBHmean, DBHmax, DBHmin & $8-4-2-1$ & 0.984 & 0.99 & 0.002 & 7.37 \\
\hline 5 & Treatment, Species & DBH, DBHmean, DBHmax, DBHmin, Age & $8-4-1$ & 0.984 & 0.99 & 0.002 & 7.37 \\
\hline 6 & Treatment, Species & DBH, DBHmean, DBHmax, DBHmin, Age & $8-4-2-1$ & 0.984 & 0.97 & 0.003 & 7.24 \\
\hline 7 & Treatment, Species & $\mathrm{DBH}, \mathrm{DH}$ & $8-4-1$ & 0.983 & 1.01 & 0.001 & 7.52 \\
\hline 8 & Treatment, Species & $\mathrm{DBH}, \mathrm{DH}$ & $8-4-2-1$ & 0.983 & 1.01 & 0.001 & 7.51 \\
\hline 9 & Treatment, Species & DBH, Age & $8-4-1$ & 0.978 & 1.14 & 0.002 & 8.47 \\
\hline 10 & Treatment, Species & DBH, Age & $8-4-2-1$ & 0.978 & 1.13 & 0.005 & 8.45 \\
\hline 11 & Treatment, Species & $\mathrm{DBH}, \mathrm{DH}$, Age & $8-4-1$ & 0.983 & 1.00 & 0.002 & 7.46 \\
\hline 12 & Treatment, Species & $\mathrm{DBH}, \mathrm{DH}, \mathrm{Age}$ & $8-4-2-1$ & 0.983 & 1.00 & 0.002 & 7.44 \\
\hline 13 & Treatment, Species & DBH, DH, Age, SA & $8-4-1$ & 0.983 & 1.00 & 0.002 & 7.43 \\
\hline$\overline{14}$ & Treatment, Species & DBH, DH, Age, SA & $8-4-2-1$ & 0.983 & 1.00 & 0.002 & $\overline{7.44}$ \\
\hline
\end{tabular}
estatísticas utilizadas para a seleção dos modelos que melhor se ajustaram aos dados.

\section{Revista Árvore 2021;45:e4512}


Table 2 - Dispersion of the percentage errors for the training and validation dataset of the best ANN's tested.

Tabela 2 - Dispersão dos erros percentuais para os conjuntos de dados de treinamento e validação das melhores RNAs testadas.

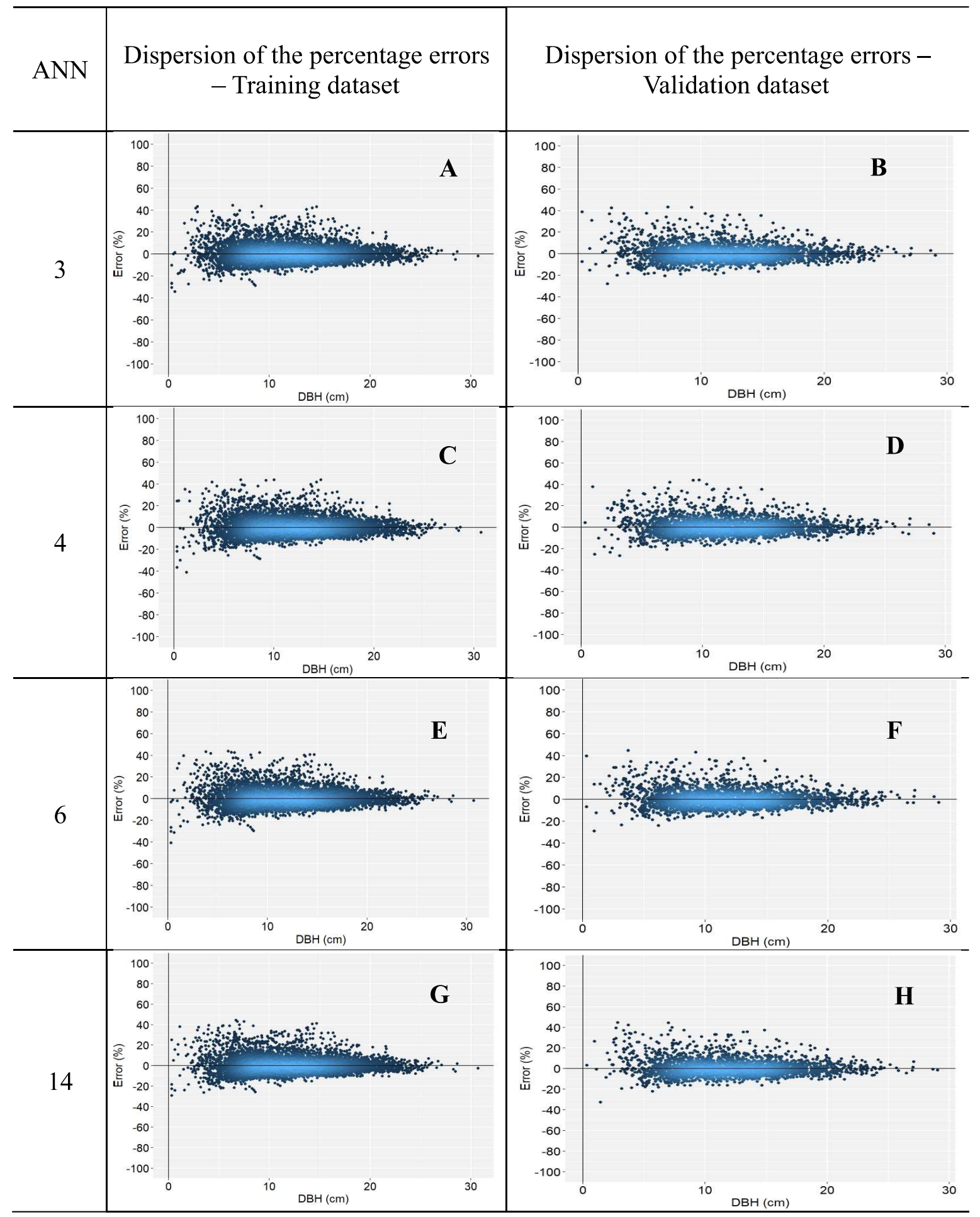




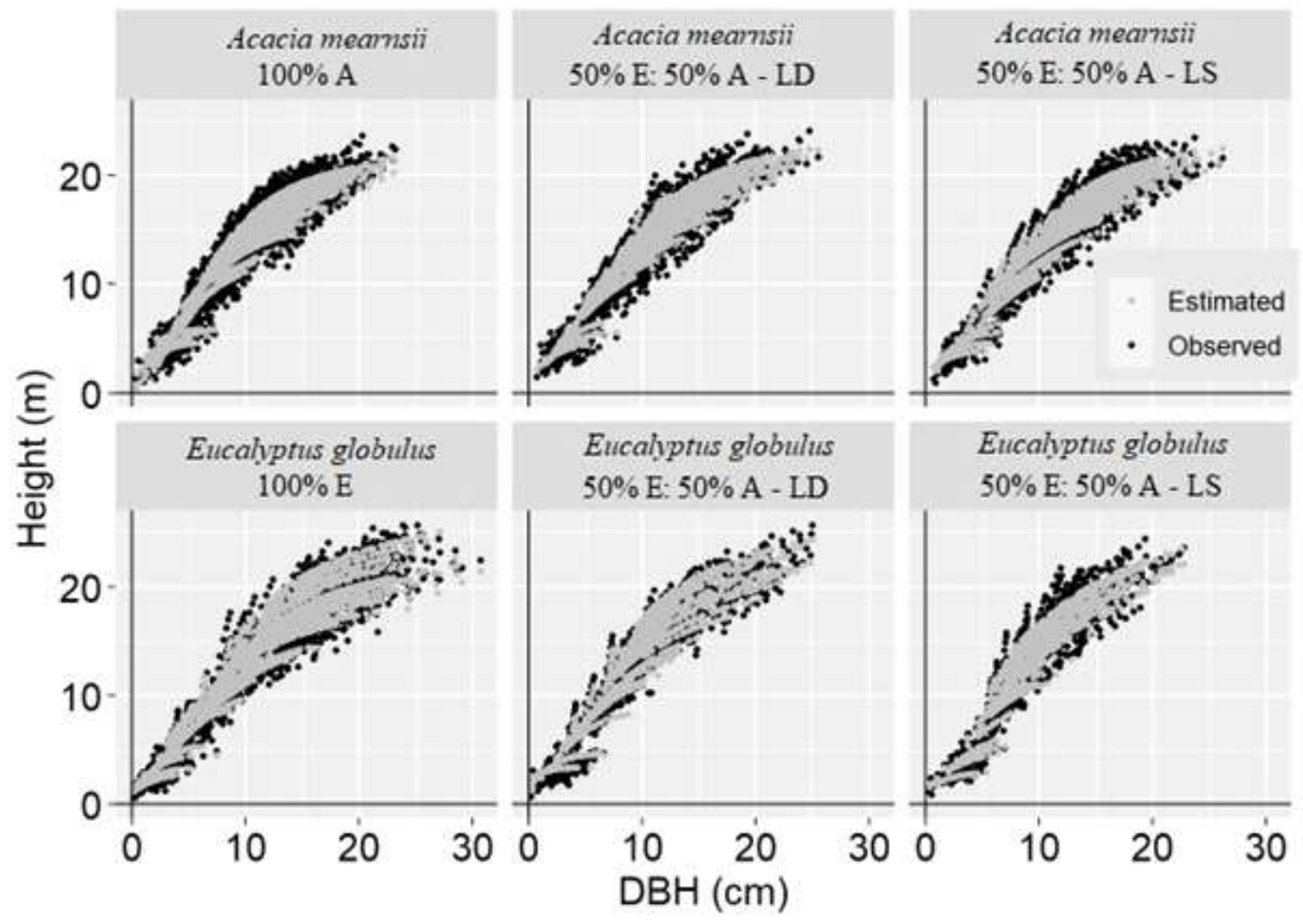

Figure 3 - The overlapping points between observed values and estimated values by ANN 3 in for each species in each treatment Figura 3 - Sobreposição dos pontos estimados sobre os observados pela RNA 3 para cada espécie em cada tratamento

plots presented in Table 2 (A - H), where the dispersion of the percentage errors for the training and validation dataset of the best ANN's are present.

According to the figures in Table 2, we can observe there were no overfitting and tendency in the dispersion of errors. Thus, the ANNs are indicated for height estimation in the evaluated situations, because they present accurate estimates and small bias, with the majority of the residues between $10 \%$ and $-10 \%$, that is shown in Table 2 .

In this study we can verify that the ANN containing only the information coming from the $\mathrm{DBH}$ as quantitative variables, the ANN 3 and 4, adjusted as well or better than RNA containing other variables, presenting the same value of 0.984 for Rŷy, respectively 0.98 and 0.99 for Syx and 7.30 and 7.37 for RMSE, that is shown in Table 1 . As can be seen in Table $2(\mathrm{~A}-\mathrm{B}, \mathrm{C}-\mathrm{D}$ and $\mathrm{E}-\mathrm{F}), \mathrm{ANN} 3,4$ and 6 presented better distribution of errors, with most of the residues in the $10 \%$ and $-10 \%$ in training and in validation datasets.

Furthermore, the ANNs were able to capture the different growth patterns shown by the species in the different forms to consortiums. In Figure 3 it is possible to observe the overlap of the observed data by the ANN 3 estimates in each of the different situations of the experiment, which demonstrates that the information of DBHmean, DBHmin and DBHmax were important attributes of the stand.

\section{DISCUSSIONS}

When analyzing the same experiment Soares et al. (2018) demonstrated that, there are significant differences between the different managements systems (i.e. mixed-species treatments and monoculture) for both species evaluated. In addition,

\section{Revista Árvore 2021;45:e4512}


the authors demonstrated that for both species their growth curves for height were different at 5\% significance based on the test L\&O test proposed by Leite and Oliveira (2002).

The differences noted in height growth is mainly due to variations of the spacings provided by maintaining the conventional planting arrangement of the species in the mixed-species treatments (Soares et al., 2018).

For all of this variation to be captured by the regression models, they are traditionally adjusted for each species in each treatment, thus providing estimates with less impartiality (Arcangeli et al., 2014). However, as can be seen in the figure 3 ANN's allows only one network to be able to model the entire data set of the study, ie, to contemplate all the variation found in the growth. In this study, ANN's could be modeled for each species, however, according to Binoti et al. (2013) it is recommended to use only one network for the entire population in order to facilitate the modeling and application process.

As observed in this study the ANNs tested showed satisfactory results for height estimation in mixed-species of Eucalyptus globulus and Acacia mearnsii, being able to capture variation in species growth. Although betters results were found in ANNs 3,4 and 6, showed in Table 1 and according Table 2 this is evidenced in the dispersion of the percentage errors, it is important to note that the best adjustments were observed in ANNs that used only variables related to $\mathrm{DBH}$, that is, a low-cost variable and easy to measure in the field.

Binoti et al. (2013) when applying ANN also for height estimation in a monoculture of Eucalyptus spp. verified that the proposed ANNs, using DBH and DH as numerical variables, and as categorical variables Age, Clone and Soil, were efficient for the estimation of tree height. The authors pointed out that by inserting additional information such as precipitation and radiation can increase the accuracy of the estimates and they recommend the measurement of height in only a few plots to monitoring of the process of the estimates generated by the networks and possible calibrations.

Several authors used ANNs with different purposes and obtained results that demonstrated their superiority as: Diamantopoulou (2005) when estimating the bark volumetric production of Pinus brutia, Silva et al. (2009) to estimate the volume of individual eucalyptus trees, Binoti (2010) when using ANN to model the growth and prognosis of production at stand level and individual tree, the author also concluded about the categorical variables, which help in the extraction of characteristics and in the solution of the problem; Diamantopoulou (2012) when estimating the individual height of trees in a practically pure forest of Abies borisii regis Mattf; Binoti et al. (2014) when using ANN for the projection of the diametric distribution of monoculture stands of Eucalyptus grandis $\mathrm{x}$ Eucalyptus urophylla hybrid; Görgens et al. $(2009,2014)$ in the volumetric estimation of individual Eucalyptus spp. and Tectona grandis trees. Freitas et al. (2020) tested the use of ANN to estimate eucalyptus productivity as a function of environmental variables, genotype and silvicultural practices and the author has conclude the ANN made it possible to estimate medium annual increment at 6 years with good precision and to include easily numerous variables, even categorical

\section{CONCLUSION}

ANN is indicated for height estimation in monocultures and mixed-species of Eucalyptus globulus and Acacia mearnsii, and with only one ANN we were able to capture the different growth patterns presented by each species, regardless of the arrangement used in the treatments, generating accurate estimates with little bias.

Depending on the homogeneity of the forest plots, few variables will need to be measured for the application of ANN in the height estimation, in some cases only the DBH may be necessary without causing precision loss. However, in order to guarantee the success of the variables to be used, they need to be tested when training and validating ANNs.

\section{AUTHOR CONTRIBUTIONS}

Augusto Arlindo Simon and Jackson Freitas Brilhante de São José provided the experimental area and part of the data and supported the entire development of the study. Luciana Duque Silva and Antonio Rioyei Higa formulated the theoretical basis of the study. Gustavo Martins Soares collected part

Revista Árvore 2021;45:e4512 
of the data and analyzed the data. Gustavo Martins Soares e Luciana Duque Silva discussed the results and wrote the paper

\section{REFERENCES}

Andrade VCL de, Leite HG. Hipsometric relationship modeling using data sampled in tree scaling and inventory plots. Revista Árvore. 2011;35(1):157164. doi: 10.1590/S0100-67622011000100019

Arcangeli C, Klopf M, Hale SE, Jenkins TAR, Hasenauer $\mathrm{H}$. The uniform height curve method for height-diameter modelling: an application to Sitka spruce in Britain. Forestry, Oxford. 2014;87(1):177186. doi: 10.1093/forestry/cpt041

Binoti DHB. Sistemas computacionais aplicados ao manejo florestal [tese]. Viçosa, MG: Universidade Federal de Viçosa; 2012.

Binoti MLMS. Redes neurais artificiais para prognose da produção de povoamentos não desbastados de eucalipto [dissertação]. Viçosa, MG: Universidade Federal de Viçosa; 2010.

Binoti MLMS, Binoti DHB, Leite HG. Aplicação de redes neurais artificiais para estimação da altura de povoamentos equiâneos de eucalipto. Revista Árvore. 2013;37(4):639-645. doi: 10.1590/S010067622013000400007.

Binoti MLMS, Binoti DHB, Leite HG, Silva AAL, Pontes C. Utilização de redes neurais artificiais para a projeção da distribuição diamétrica de povoamento equiâneos. Revista Árvore. 2014;38(4):747-754. doi: 10.1590/S0100-67622014000400018.

Braga A de P, Carvalho AP de LF de, Ludemir TB. Redes Neurais Artificiais: Teoria e Aplicações. Rio de Janeiro, RJ: Editora LTC; 2000.

Bullinaria JA. Introduction to Neural Computation. Notas de aula. Disponível em: http://www.cs.bham. ac.uk/ jxb/inc.html. 2014. Acesso em: 20 jun. 2020.

Campos JCC, Leite HG. Mensuração florestal: perguntas e respostas. 3. ed. Viçosa: Universidade Federal de Viçosa; 2009.

Colbert KC, Larsen DR, Lootens JR. Heightdiameter equations for thirteen Midwestern bottomland hardwood species. Northerm Journal of
Applied Forestry. 2002;19(4):171-176. doi: 10.1093/ njaf/19.4.171.

Freitas ECS de, Paiva HN de, Neves JCL, Marcatti GE, Leite HG. Modeling of eucalyptus productivity with artificial neural networks. Industrial Crops and Products. 2020;146:112-149. doi: 10.1016/j. indcrop.2020.112149.

Diamantopoulou MJ. Artificial neural networks as an alternative tool in pine bark volume estimation. Computers and electronics in agriculture. 2005;48(3):235-244.doi: 10.1016/j. compag.2005.04.002.

Diamantopoulou MJ. Assesing a reiable modeling approach of features of trees through neural network models for sustainable forests. Sustainable Computing: Informatics and Systems. 2012;2(4):190- 197. doi: 0.1016/j. suscom.2012.10.002.

Dowla UF, Rogers L. Solving Problems in Environmental Engineering and Geosciences with Artificial Neural Networks. Cambridge, MA: MIT Press; 1995.

Dykstra DP. Presents a simple two variable land management linear programming model. In: Buongiorno J, Gilless JK, editors. Decision Methods for Forest Resource Management. Mathematical programming for natural resource management. New York: McGraw- Hill; 1984. p. 15-38.

Finger CAG. Fundamentos de biometria florestal. Santa Maria: UFSM, Centro de Pesquisas Florestais; 1992.

Görgens EB, Leite HG, Gleriani JM, Soares CPBS, Ceolin A. Influência da arquitetura a estimativa de volume de árvores individuais opor meio de redes neurais artificiais. Revista Árvore. 2014;38(2):289295. doi: 10.1590/S0100-67622014000200009.

Görgens E, Leite HG, Santos HN, Gleriani JM. Estimação do volume de árvores utilizando redes neurais artificiais. Revista Árvore. 2009;33(6):11411147. doi: 10.1590/S0100-67622009000600016.

Gurney K. An Introduction to Neural Networks. London: Prentice Hall; 1999.

Günther F, Fritsch S. Neuralnet: Training of neural

Revista Árvore 2021;45:e4512 
networks. The R journal. 2010;2(1):30-38.

Haykin S. Redes neurais: princípios e prática. 2. ed. Porto Alegre: Bookman; 2001.

Jorge DL, Silva JAA da, Gadelha FH de L, Ferreira RLC. Análise e comparação de modelos de relação hipsométrica para clones de Eucalyptus sp. cultivados na região do pólo gesseiro do Araripe. In: VI Semana nacional de ciência e tecnologia. 2009, Recife. Recife: Universidade Federal de Pernambuco; 2009; 1-3.

Ker J, Smith J. Sampling for height-diameter relationships. Journal of forestry. 1957;55(3): 205 207. doi: 10.1093/jof/55.3.205

Leite HG, Andrade VCL DE. Importância das variáveis altura dominante e altura total em equações hipsométricas e volumétricas. Revista Árvore. 2003;27(3):301-310.

Leite HG, Oliveira FHT. Statistical procedure to test the identity of analytical methods. Communications in Soil Science and Plant Analysis. 2002;33(7/8):1105-1118. doi: 10.1081/CSS120003875

Loetsch F, Zohrer F, Haller KE. Forest inventory. v.2. Munchen: BLV Verlagsgesellschaft; 1973.

Moreno JA. Clima do Rio Grande do Sul. Porto Alegre: Secretaria da Agricultura;1961.

Riedmiller M, Braun H. RPROP-A fast adaptive learning algorithm. Proc. of ISCIS VII, Universitat, 1992.
Riedmiller M, Braun H. A direct adaptive method for faster backpropagation learning: The RPROP algorithm. Neural Networks. International Conference On IEEE, 1993.

Scolforo JR. Biometria florestal: técnicas de regressão aplicada para estimar volume, biomassa, relação hipsométrica e múltiplos produtos de madeira. Belo Horizonte: CEMIG; Lavras: UFLA; FAEPE; 1997.

Silva MLM, Binoti DHB, Gleriani JM, Leite HG. Ajuste do modelo de Schumacher e Hall e aplicação de redes neurais artificiais para estimar volume de árvores de eucalipto. Revista Árvore. 2009;33(6):1133-1139.

Soares GM, Silva LD, Higa AR, Simon AA, São José JFB. Crescimento de Acacia mearnsii De Wild e Eucalyptus globulus Labill em monocultivos e consórcios com linhas simples e duplas de plantio. Scientia Forestalis. 2018;46(4): 1-10. doi: 10.18671/ scifor.v46n120.06

Souza CAM, Almeida AQ, Almeida VVS, Silva GF. Comparação entre modelos de relações hipsométricas para estudo de uma floresta de Eucalyptus urophylla. In: X Encontro latino americano de iniciação cientifica e VI Encontro latino americano de pós graduação. 2006, São José dos Campos. São José dos Campos: Universidade do Vale do Paraíba; 2006. P 2850-2853.

Zanon MLB, Finguer CAG, Schneider PR, Klein JEM, Coelho MCB. Funções para descrever a relação altura e diâmetro de Eucalyptus dunnii Maiden. Ciência Rural. 1996;26(1): 87-90. 